\title{
Reducing bias in shopping mall-intercept surveys: the time-based systematic sampling method
}

\author{
Johan de W. Bruwer* \& Norbert E. Haydam \\ School of Management, Cape Technikon, P.O. Box 652, Cape Town, 8000 Republic of South Africa
}

\author{
Binshan Lin \\ Department of Management and Marketing, College of Business Administration, Louisiana State University, Shreveport, \\ Louisiana, United States of America
}

Accepted March 1996

\begin{abstract}
Marketing practitioners nowadays often have to base important management decisions on information obtained in research surveys conducted in shopping malls. The shcpping mall-intercept survey is a very popular method used by research agencies to gather information of almost all kinds. While the advantages of shopping mall-intercept interviewing are considerable, their adoption without recognition of their shortcomings is not prudent. Selection error, resulting in time sampling bias, occurs in shopping mall-intercept surveys as a result of significant differences between the characteristics of persons visiting a shopping mall at different time segments during a month period. In this empirical study, the authors explain the problem of time-based selection error in mall-intercept data, the failure of common research practices to correct it. and develop a specific time-bias reduction technique.
\end{abstract}

\begin{abstract}
Bemarkingspraktisyns moet hedendaags dikwels belangrike bestuursbesluite baseer op navorsingsinligting wat verkry word uit navorsingstudies wat in winkelsentrums uitgevoer is. Die winkelsentrum-onderskep-onderboudvoermetode is ' $n$ baie gewilde metode wat deur navorsingsagentskappe gebruik word om bykans alle tipes inligting in te samel. Hoewel die voordele wat winkelsentrum-onderskep-onderhoude inhou aansienlik is, is die toepassing daarvan sonder inagneming van hulle tekortkominge, baie kortsigtig. Seleksiefoute, wat tydgebaseerde vooroordeel tot gevolg het, kom in winkelsentrumonderskep-onderhoude voor as gevolg van beduidende verskille wat bestaan tussen die eienskappe van persone wat die winkelsentrum tydens verskillende tydsegmente gedurende 'n periode van 'n maand besoek. In hierdie empiriese navorsingstudie verduidelik die outeurs die probleem van tydgebaseerde seleksiefout in winkelsentrum-onderskep-data, die onvermoë van alledaagse navorsingstegnieke om dit te beperk, en word 'n nuwe steekproefnemingstegniek ontwikkel ten einde hierdie vooroordeel te verminder.
\end{abstract}

*Author to whom correspondence should be addressed.

\section{Introduction}

Marketing practitioners base vital business decisions on available market research information. Gathering marketing research information for decision-making purposes, is an expensive item in the product or service marketing process. The personal interviewing technique is often used to gather the required information. Shopping mall-intercept interviews are the predominant type of personal interview these days in the United States (Hawkins \& Tull, 1994: 134), and as a result of this increasing popularity, they are second only to telephone surveys in usage (Nowell \& Stanley, 1991: 475). The popularity of shopping mall interviewing appears to be a worldwide trend, when considering that in Europe, most personal interviews are conducted at a central location (that is a market or shopping centre), or in the streets (France and the Netherlands), or at home, or at work (United Kingdom and Switzerland (Demby, 1990: 24)). Evidence of the shift in the mode of personal interviewing can be found in the fact that $86 \%$ of the largest United States consumer goods and services companies are using shopping mall-intercept interviews against only $39 \%$ using in-home personal interviews (Market Facts, Inc., 1987: 23).

Shopping mall-intercept interviewing involves exactly what the name implies - stopping or intercepting shoppers in a mall at random, qualifying them if necessary, asking whether they would be willing to participate in a research study, and conducting the interview right on the spot or taking them to the research agency's interviewing facilities located in the mall (Churchill, 1992: 275).

The increased usage of shopping mall-intercept surveys can be attributed mainly to their cost advantage over in-home surveys and the use of a central location frequented by large numbers of the target population. In addition, it carries several other advantages over door-to-door (in-home) interviewing. The mall-intercept is more flexible and versatile than in-home personal surveys. The overall quality of data collected appears to be equivalent, at least, to that of telephone interviewing in terms of the ability to provide complete and in-depth responses (Bush \& Parasuraman, 1985: 42).

However, while the pragmatic advantages of shopping mall-intercepts are considerable, their adoption without recognition of their shortcomings is not prudent according to Murry et al. (1989: 46). Their convenience thus also gives rise to problems in obtaining a representative sample of the target population. Authors such as Reid (1984: 16), on the other hand, disagree with this viewpoint as some studies have indicated that $95 \%$ of all adults in a geographic area shop in a mall at least once a year and two-thirds of the households do so in a given two-week period.

Both Sudman (1980: 423) and Blair (1983: 98) state that samples from shopping centre surveys are selected in thaphazard ways'. It must also be remembered that individuals who visit shopping malls are not representative of the entire population of a mall's trade area, a standard metropolitan statistical area (SMSA) or area of dominant influence (ADI) (Aaker \& Day, 1990: 114). Results are only applicable to the 
shopping mall in question and cannot be extrapolated onto the universe other than that of the shopping mall itself (Zikmund, 1994: 198). This is not a serious drawback, as only in some cases do shopping mall management want to generalize to the total population, for example, when an ideal tenant mix for the mall needs to be established.

Murry et al. (1989: 46) are of the opinion that a distinguishing source of error in mall-intercept data is selection error. This selection error depicts a lack of representativeness due to, firstly, a sample frame's inadequacy as a population list, and, secondly, the use of non-probability methods to sample the list or frame.

According to Dupont (1987: 45) mall-intercept surveys have been virtually ignored in marketing research texts and in the marketing and research literature. Although authors such as Boyd et al. (1985: 197) and Dillon et al. (1993: 173) acknowledged the circumstances in which mall-intercepts are particularly appropriate, Dupont (1987: 45) and others remain convinced that marketing researchers must still defend it as a valid research technique.

Despite the lack of published research on mall-intercept sampling, some methods to prevent or remedy at least some of the problems in obtaining a rcpresentative sample in mallintercept surveys have nevertheless been cited in the literature. Most notable are those of Nakanishi (1978 - frequency bias); Sudman (1980 - probability sampling and weighting procedures); Blair (1983 - length-bias); Dupont (1987), and Murry, et al. (1989 - both demographic weighting); and Nowell \& Stanley (1991 - length-bias).

As the characteristics of persons visiting the shopping centre vary by season of the year, week of the month. day of the week, time of the day, etc., time sampling bias also occurs in shopping mall-intercept surveys. Of the abovc-mentioned authors, only Sudman (1980: 426) suggests that time-based sampling be executed to account for time sampling bias. However, the magnitude of this form of sampling bias and a practical type of remedial action are not addressed. This article does both.

The lack of published research on mall-intercept interviewing, mentioned before, is hard to understand, given the widespread use of the technique among market researchers. The best example of this symptom is probably encapsulated in the following statement of Dupont

‘... most "casual" mall samples are fairly self-weighted on the dimension of time sampling, so long as interviewing is carried out over a period of at least a week'

(1987: 47).

This study, therefore, specifically addresses this gap in the survey research literature of reducing selection error in mallintercept interviewing.

Accordingly, the purpose of this study is to empirically demonstrate that the traditional ('popular') methods adopted by research houses to sample during month-end in shopping mall-intercept surveys results in considerable time-based selection error. This article documents an assessment of the problem of time-based selection error in mall-intercept data, and even more important, the failure of common research practices for effectively correcting it. Consequently, a timebased systematic sampling method, which should be of value to marketing practitioners and marketing researchers alike, is developed to reduce mall-intercept sample bias.

\section{Sampling biases in mall-intercept interviewing}

Shopping mall-intercept surveys are, unfortunately, vulnerable to haphazard sampling procedures that introduce biases of unknown magnitude into their results (Blair, 1983: 98). The following summarizes the common sampling bias problems encountered with mall-intercept interviews :

'Unless the sampling plan is devised carefully, however, the results of mall-intercept sampling are subject to potentially large selection biases. These biases result from variations in the demographic composition of shoppers from that of the population as a whole by shopping centre, by day and time of the day, and by location in the shopping centre, as well as the biases that potentially arise from how individual shoppers are selected' (Tull \& Hawkins, 1990: 483).

Murry et al. (1989: 46) state that traditional ('popular') shopping mall sampling violates the key assumption of a simple random sample, as a result of :

- Quota sampling usually predominating;

- Interviewers are typically left to their own discretion in selecting respondents; and

- Interviewers will primarily interview respondents most like themselves and/or interview only readily available shoppers.

Sample control has always been the big issue in shopping mall-intercept surveys. Regarding the sample control of the mall-intercept interview, there are two primary problems facing the researcher (Dillon et al., 1990: 199):

- Frequent mall shoppers have a greater chance of being included in the sample. Their length of stay in the mall during a shopping trip (known as length-biasedness) presents the same problem. These problems are complicated further as interviewing is often limited to Thursday, Friday and Saturday shoppers only.

- A potential respondent can intentionally avoid or initiate contact with the interviewer. Furthermore, the demographics and lifestyles of shoppers can vary drastically from mall to mall and even from day to day.

Therefore, the construction of a proper sampling plan is crucial when it comes to the elimination of potentially large biases. The way to evaluate a sample is not by the results the characteristics of the sample - but by examining the process by which it was selected. The first step in evaluating the quality of a sample is to define the sample frame. Fowler (1993: 12) states that there are three characteristics of the sample frame that a researcher should evaluate: 'comprehensiveness, probability of selection, and efficiency'.

The question remains: which accepted sampling methods/ plans are commonly used in shopping mall-intercept surveys?

The simplest way of sampling would be to interview any person (whether random or qualified) at any time of the month. In the United States, some shopping malls rent space to researchers on a monthly basis, and as a result, there is every incentive for them to smooth out the use of facilities. However, most research houses elect to sample during monthend because shopping malls have a high incidence of shopper traffic during this period which has definite cost and time 
saving advantages. To make matters even worse, most of these surveys are designed to produce some desired number of completed interviews within a three-day (or even shorter) interviewing period. Interviewers enter the centre on busy days, usually Thursday, Friday, and/or Saturday, and interview shoppers on a catch-as-catch-can basis until the desired sample size is reached or until the allotted time is exhausted. Daily sample size quotas may be set, and it is common for interviewing to end in the early afternoon upon completion of the daily quota (Blair, 1983: 99). This method assumes, of course, that the mid-month shopper has the same shopper profile as the month-end shopper. This hypothesis is tested in the following section.

Sampling can also be done during the month on the same time interval basis, that is every hour. This would, however, not be representative unless an equal number of shoppers visit the mall each hour and day. This is certainly not the case since it is well known that different shopping malls have different shopper traffic and demographic profile patterns.

Another method would be to interview every $n^{\text {th }}$ person entering the shopping mall at the various entrances of the mall. This method would reflect the traffic flow of the particular month but requires an accurate estimate of the number of shoppers who enter the shopping mall. One loses complete control over the sample size should the sample be drawn over the period of a full month which could be in itself a very costineffective exercise.

It is clear that shopping mall-intercept surveys, like any other research survey method, are subject to sampling bias and selection error. There is, however, no acceptable excuse (even cost-wise) for haphazard sampling procedures that mall-intercepts are being accused of depicting. It is believed that time-based sampling can go a long way toward solving the problems of time- and length-biasedness. In order to draw a sample which would accurately reflect both the traffic flow and the demographic and lifestyle profiles of shoppers in a shopping mall, a specific sampling method, as detailed in the next section, was devised.

\section{Research methodology}

To examine the importance of time-sampling issues, data from several shopping mall-intercept surveys should be assembled. However, only one such survey will be discussed in this article because one example could be much better controlled and monitored and allows for a more focussed discussion of results. Of necessity, the name and some of the findings have been disguised to maintain client confidentiality. The survey was conducted in a fairly large shopping mall in the Bellville magisterial area (SMSA) near Cape Town in the Republic of South Africa.

Though the simplest design is to sample all eligible time periods with equal probability, this is not an efficient design (Sudman, 1980: 426). The solution is sampling time periods with probabilities proportionate to the number of customers expected in the time period which is self-weighting.

Because of the location of traffic routes, parking used by persons driving themselves, and public transportation facilities, one entrance in the shopping mall may draw from very different neighborhoods than another (Aaker \& Day, 1990: 372). Not all entrances receive equal use, therefore, an un- biased sample would require that entrances be sampled with probabilities in proportion to the fraction of customers attracted. A solution is to stratify by entrance location and to take a separate sample from each entrance - analogous to an area cluster sample.

In order to comply with the principle of stratified proportionate sampling per entrance, measures of visits by time segments (periods) were obtained from previous electronic 'headcounts' of all the shoppers entering and exiting the shopping mall for a period of four months prior to the start of the fieldwork. The shopper time segment patterns for each of the three entrances to the mall were also established and a time-based systematic sample was then drawn. This involved a sample being drawn over the period of exactly one calender month from August 26th to September 25th, stratified per time segment, to be directly proportionate to the actual shopper time segment patterns established earlier.

For example, on Friday August 28th, a total of 21 shoppers were interviewed during the time segment $13: 00$ to $17: 30$. This resulted in an interview starting exactly at time intervals of 13 minutes apart, that is a total of 270 available minutes for the afternoon session during which. 21 interviews had to be conducted at the three entrances - the first interview starting at $13: 00$ and the last at $17: 17$.

Careful sampling necessitates intercepting shoppers as they cross a real or imaginary line upon entrance to the mall. In this regard, there are two issues - eligibility and ties (two or more persons shopping together). In the case of a tie, ordering of persons who become eligible simultaneously is required. Sudman (1980: 426) suggests that a simple rule to order is from left to right or from east to west. The first person crossing the line at each interview point at the predetermined time point, that is 13:13 for entrance number one, was then interviewed. This completely eliminated the length-bias sampling problem cautioned against by Nowell \& Stanley (1991). Due to the continuous heavy shopper traffic, the non-response factor of about $40 \%$ also did not present a problem regarding keeping to the time schedule. This compares favourably with the non-response rate of mall intercepts which normally varies between $10 \%$ and $50 \%$ and which is only slightly lower than that of telephone surveys (Bush \& Hair, 1985: 165). A further measure to improve data quality was to instruct interviewers experiencing a refusal (non-response) to be interviewed at the predetermined time point to intercept and interview the very next similar shopper. Therefore if the refusal was a white female, the next intercept would be the same type of person. Intercepts at each entrance were weighted in accordance with the previously established actual shopper flows. The following day (Saturday), 26 respondents were interviewed at intervals of 10 minutes apart, reflecting the heavier shopper traffic pattern compared to the month-end Friday, and so on.

Furthermore, the days of the month were divided into morning and afternoon sessions. The initial morning (and day) session was selected on a random start basis and altered thereafter. The fourth week of the month, which can vary in length between seven and ten days, has been divided into two parts, namely week $4 A$ and week 4B. This enables the researcher to sample the month-end shopper in both sub-weeks, an essential requirement in the sampling methodology 
described in the following sections of the article. This sampling technique, clustering over time, has a twofold advantage in terms of time and cost saving (Alreck \& Settle, 1985: 86).

In total, 408 respondents were interviewed which fell comfortably within the $95 \%$ confidence level given a $5 \%$ margin of error for the total (predetermined) monthly shopper population of the mall.

The above-mentioned method has the distinct advantage that great care was taken to ensure that the sample drawn reflected the actual shopper flow patterns and respondent profile of the shopping mall visitor by using a time-based systematic random sampling technique. The one drawback of this method, also cited by Blair (1983: 105), is that it is not efficient for interviewer scheduling, resulting in increased interviewing costs as fieldworkers no longer were paid per interview but were remunerated on a daily basis. However, the authors disagree with Blair's (1983: 106) statement that '... such procedures would raise the cost of a shopper survey dramatically', as the extent of the increase experienced in this study amounted to only $15 \%$ on the total cost factor - a small 'sacrifice' given the ensuing improvement in data quality and decrease in sampling bias. This cost factor excludes the four month surveillance period during which data gathering of traffic flows took place. The rationale for this is that many shopping malls have installed electronic equipment for headcount purposes in any event with the intention to use the data to attract tenants to the mall. Therefore, this is not regarded as a primary cost item of this research method. Careful interviewer time scheduling resulted in an interviewer completing an interview and moving immediately to another entrance in time for the interview to be held at that point. Blair (1983: 99) certainly oversimplifies in terms of stating that an interviewer is required for every entrance of a mall. This is not so, and not even at peak traffic hours during month-end Saturday mornings, was an interviewer required per entrance as a result of efficient time scheduling.

The focus of this article is to determine whether the demographic, lifestyle and user behaviour profile of shoppers obtained through the suggested sampling procedure is significantly different from that of the other more 'traditional' sampling methods. This hypothesis will forthwith be tested.

\section{Hypothesis}

The aim of the research was to establish whether the 'end-ofthe-month' shopper (of which three different definitions are provided) differs significantly from the shopper who visits the shopping mall during the rest of the month, in other words, the so-called 'mid-month' shopper.

Demographic, lifestyle and user behaviour data depicting these two types of shoppers were extracted from the main sample $(n=408)$ to form two independent samples. The Two-Independent Sample Proportion Test ${ }^{1}$ was then conducted on a total of 14 different demographic, lifestyle and user behaviour variables. The nine demographic variables are standard shopper profile variables used to describe the mall visitor, similar to those used by Sudman (1980) in his study. The balance of the variables consists of two lifestyle and three user behaviour variables, which, according to Murry et al. (1989: 49) and Bush \& Hair (1985: 162), are dependent variables. It must also be remembered that the standard demo. graphic variables aside, the uniqueness of each shopping mall could necessitate that a different set of unique lifestyle and user behaviour variables be used. However, the issue whether significant differences between month-end and mid-month shoppers in that mall exist, remains.

The hypothesis is therefore stated as:

$H_{0}: \pi_{1}=\pi_{2}$

$\mathrm{H}_{1}: \pi_{1} \neq \pi_{2}$

In other words, the respondent profile obtained in sample 1 (the mid-month shopper) equates to the respondent profile obtained in sample 2 (the month-end shopper). Therefore, if $Z_{c}=\left(p_{1}-p_{2}\right) /\left(S p_{1}-p_{2}\right)$ and $Z_{t}=Z_{1}(1-\alpha)$ the $H_{0}$ will be re. jected if $Z_{c}>Z_{1}\left(Z_{c}= \pm 1.96\right.$ for $\left.\alpha=0.05\right)$.

The following respondent variables, depicting demographics, lifestyle and user behaviour were used:

\section{Residential suburb}

The proportion of shoppers living outside the ten kilometer catchment area of the shopping mall.

\section{Average amount spend per shopping trip}

The proportion of shoppers who on average spend less than R100 per shopping trip.

\section{Method of payment}

The proportion of shoppers who paid for purchases in cash or by cheque.

\section{Method of remuneration}

The proportion of shoppers who are monthly remunerated.

\section{Monthly income of household}

The proportion of shoppers who earn less than R2 000 per month in the household.

\section{Shopper's occupation}

The proportion of shoppers who are not economically active. This include housewives, pensioners, students, as well as respondents who have stated that they are unemployed.

\section{Marital status}

The proportion of shoppers who are married.

\section{Number of children under the age of 18 years}

The proportion of shoppers who have two dependent children or less living in their family household.

\section{Home language}

The proportion of shoppers who are not English speaking.

Age

The proportion of shoppers between the ages of $25-49$ years.

\section{Gender}

The proportion of shoppers who are female. 


\section{Ethnic group}

The proportion of shoppers who are Black South Africans.

\section{Reason for shopping}

As the shopping mall's anchor tenant is a major supermarket outlet, the hypothesis is tested against the reason stated for shopping other than for groceries and household goods.

\section{Frequency of mall visit}

The proportion of shoppers who stated that they have visited the mall not more than twice in the past month.

Except for the first demographic variable (residential area) which was selected on the basis of the shopper residing outside the shopping mall's primary catchment area, all other demographic, lifestyle and user behaviour variables were selected on the basis of the largest proportion of the variable.

In order to create a clear distinction between the month-end shopper and the mid-month shopper a so-called 'grey area' was used to separate the two independent samples. The 'grey area' is defined as shoppers who visited the mall two days before and two days after the so-called month-end shopper. In other words:

Mid-month 'Grey area' Month-end'
shopper 2 days $\quad$ shopper 2 days 2 shopper

Shoppers sampled during the 'grey area' period were filtered out of the sample. Table 1 depicts the sampling schedule distribution and indicates the method used for identifying respondents in the 'grey area'. For example, a total of 62 respondents fell in the 'grey area' of the month-end shopper as per definition number 1 , and 85 and 60 respectively as per definitions numbers 2 and 3 , and were consequently filtered out of the sample (refer to Tables 1 and 3).

\section{Research results}

Three different definitions of month-end shoppers were devised for the purposes of statistical testing:

\section{Month-end shopper definition 1}

Month-end shopper: last Thursday, Friday and Saturday of the month (refer to Table 2).

The mid-month shopper, who is defined as the shopper who visited the shopping mall on times other than the last Friday, Saturday and Sunday of the month, differs significantly (at least at the $95 \%$ confidence level, $=0.05$ ) on six of the 14 respondent variables from the month-end shopper. These variables are: age, marital status, number of children in the household, home language (demographic); reason for shopping (lifestyle); and average amount spend (user behaviour).

As a consumer ages, needs, wants, and preferences for products and activities (lifestyle) tend to change (Solomon, 1996: 396). The variables age, marital status and number of children in the household are systematically combined in a composite variable described as the family life cycle (FLC). Income constraints and family responsibilities define many of the purchase decisions and much of the purchase behaviour of families along the traditional FLC (Schiffman \& Kanuk, 1994: 361). During the parenthood (full nest) stage of the FLC, the mobility of parents to visit shopping malls are often impeded due to family responsibilities and during this stage,
Table 1 Sampling schedule distribution

\begin{tabular}{|c|c|c|c|c|}
\hline $\begin{array}{l}\text { Day of } \\
\text { month }\end{array}$ & $\begin{array}{l}\text { Day of } \\
\text { week }\end{array}$ & $\begin{array}{c}\text { Week } \\
\text { number }\end{array}$ & $\begin{array}{l}\text { Number of } \\
\text { respondents }\end{array}$ & $\begin{array}{l}\text { Week } \\
\text { total }\end{array}$ \\
\hline$\overline{26}$ & Wednesday & $4 B$ & $10^{* *}$ & \\
\hline 27 & Thursday & 4B & $15^{*}$ & 72 \\
\hline 28 & Friday & 4B & $21^{*}$ & \\
\hline 29 & Saturday & 4B & $26^{*}$ & \\
\hline 31 & Monday & 1 & $12^{* *}$ & \\
\hline 1 & Tuesday & 1 & $12^{* *}$ & \\
\hline 2 & Wednesday & 1 & 15 & \\
\hline 3 & Thursday & 1 & 14 & 95 \\
\hline 4 & Friday & 1 & 21 & \\
\hline 5 & Saturday & 1 & 21 & \\
\hline 7 & Monday & 2 & 15 & \\
\hline 8 & Tuesday & 2 & 10 & \\
\hline 9 & Wednesday & 2 & 12 & \\
\hline 10 & Thursday & 2 & 11 & 96 \\
\hline 11 & Friday & 2 & 19 & \\
\hline 12 & Saturday & 2 & 20 & \\
\hline 13 & Sunday & 2 & 9 & \\
\hline 14 & Monday & 3 & 11 & \\
\hline 15 & Tuesday & 3 & 7 & \\
\hline 16 & Wednesday & 3 & 8 & \\
\hline 17 & Thursday & 3 & 9 & 65 \\
\hline 18 & Friday & 3 & 17 & \\
\hline 19 & Saturday & 3 & 13 & \\
\hline 21 & Monday & $4 \mathrm{~A}$ & 16 & \\
\hline 22 & Tuesday & $4 \mathrm{~A}$ & $18^{* *}$ & \\
\hline 23 & Wednesday & $4 \mathrm{~A}$ & $10^{* *}$ & 80 \\
\hline 24 & Thursday & $4 \mathrm{~A}$ & $15 *$ & \\
\hline \multirow[t]{2}{*}{25} & Friday & $4 \mathrm{~A}$ & $21^{*}$ & \\
\hline & & & $n=408$ & \\
\hline $\begin{array}{l}\text { * Montl } \\
\text { * 'Gre }\end{array}$ & $\begin{array}{l}\text { opper (shopp } \\
\text { shopper defir }\end{array}$ & $\begin{array}{l}\text { nition no.1 } \\
\text { (62 respo }\end{array}$ & $\begin{array}{l}\text { respondents } \\
\text { nts - see Tab }\end{array}$ & \\
\hline
\end{tabular}

both parents are also likely to have to work as a result of the need for increased income in the household. On the other hand, people in the bachelorhood, newlywed, post-parenthood (empty nest) and solitary survivor stages of the FLC, often exhibit different shopping patterns due to the relative freedom of movement they enjoy. In families where both parents work, a high incidence of evening, weekend, and particularly month-end shopping occur. Shopping malls could organize special events such as fashion shows or puppet shows, for adults and/or children in the mall during weekends, particularly at month-end. As a significant difference was found between the home language of month-end and mid-month shoppers, these special events or activities could be congruent with the home language of the month-end shopper.

A discussion of the significantly different lifestyle and user behaviour variables is given under 'month-end shopper definition 2'. 
Table 2 Month-end shopper: definition 1

\begin{tabular}{lcccc}
\hline Respondent characteristic & $\begin{array}{c}\text { Mid-month } \\
\mathrm{n}=248\end{array}$ & $\begin{array}{c}\text { Month-end } \\
\mathrm{n}=98\end{array}$ & $\begin{array}{c}\mathrm{Z}_{\mathrm{t}} \\
\text { value }\end{array}$ & $\begin{array}{c}\text { t-Statistic } \\
\text { probability }\end{array}$ \\
\hline Residential area & 0.585 & 0.587 & -0.0274 & 0.3988 \\
Average amount spend & 0.681 & 0.439 & 4.1631 & $0.0000^{* *}$ \\
Method of payment & 0.853 & 0.922 & -1.7341 & 0.0893 \\
Remuneration method & 0.733 & 0.676 & 1.0604 & 0.2275 \\
Income of household & 0.544 & 0.521 & 0.3866 & 0.3697 \\
Occupation & 0.145 & 0.214 & -1.5597 & 0.1182 \\
Marital status & 0.480 & 0.612 & -2.2139 & $0.0347^{*}$ \\
Number of children & 0.742 & 0.592 & 2.7421 & $0.0093^{* *}$ \\
Home language & 0.657 & 0.786 & -2.3451 & $0.0252^{*}$ \\
Age & 0.540 & 0.673 & -2.2568 & $0.0310^{*}$ \\
Gender & 0.766 & 0.765 & 0.0198 & 0.3989 \\
Ethnic group & 0.782 & 0.857 & -1.5812 & 0.1145 \\
Reason for shopping & 0.092 & 0.168 & -2.0579 & $0.0488 *$ \\
Shopping frequency & 0.407 & 0.296 & 1.9210 & 0.0632 \\
\hline * Significant at 95\% confidence level & & & \\
** Significant at 99\% confidence level & & & \\
\hline
\end{tabular}

\section{Month-end shopper definition 2}

Month-end shopper: last Friday of the month until the second day of the following month.

From Table 3 it can be seen that if the sampling of the month-end shopper had taken place from the last Friday of the month until the second day of the following month, the demographic, lifestyle and user behaviour proportions differ significantly on three counts: reason for shopping (lifestyle), average amount spend (user behaviour), and income of the household (demographic variable).

A direct correlation exists between the income level of a household and its purchasing power (Assael, 1995: 352). Household income is an important variable for distinguishing consumer market segments. However, the major problem with segmenting a market on the basis of income alone is that income simply indicates the household's ability (or inability) to pay for a product or service, while other factors such as lifestyle, personal taste and values also play a major role in the behaviour of consumers (Schiffman \& Kanuk, 1994: 57). Education, occupation, and income tend to be closely related in almost a cause-and-effect relationship. High-income households are inclined to shop less regularly at a mall, but the average amount spend per shopping expedition will be higher, explaining the high level of significance of the variable 'average amount spend' in the case of all three month-end shopper definitions. The shopping mall in which the study

Table 3 Month-end shopper: definition 2

\begin{tabular}{lcccc}
\hline Respondent characteristic & $\begin{array}{c}\text { Mid-month } \\
\mathrm{n}=216\end{array}$ & $\begin{array}{c}\text { Month-end } \\
\mathrm{n}=107\end{array}$ & $\begin{array}{c}\mathrm{Z}_{\text {- }} \\
\text { value }\end{array}$ & $\begin{array}{c}\text { t-Statistic } \\
\text { probability }\end{array}$ \\
\hline Residential area & 0.585 & 0.562 & 0.3233 & 0.3790 \\
Average amount spend & 0.699 & 0.477 & 3.8799 & $0.0002 * *$ \\
Method of payment & 0.855 & 0.868 & -0.3163 & 0.3790 \\
Remuneration method & 0.701 & 0.723 & -0.4094 & 0.3668 \\
Income of household & 0.574 & 0.443 & 2.2204 & $0.0339 *$ \\
Occupation & 0.167 & 0.150 & 0.3909 & 0.3697 \\
Marital status & 0.505 & 0.523 & -0.3046 & 0.3802 \\
Number of children & 0.736 & 0.692 & 0.8302 & 0.2827 \\
Home language & 0.685 & 0.729 & -0.1340 & 0.3956 \\
Age & 0.556 & 0.645 & -1.5282 & 0.1238 \\
Gender & 0.764 & 0.712 & 1.0115 & 0.2396 \\
Ethnic group & 0.806 & 0.811 & -0.1073 & 0.3965 \\
Reason for shopping & 0.074 & 0.165 & -2.5201 & $0.0167 *$ \\
Shopping frequency & 0.412 & 0.374 & 0.6563 & 0.3209 \\
\hline * Significant at 95\% confidence level & & & \\
** Significant at 99\% confidence level & & & \\
\hline
\end{tabular}


was conducted, serves a high percentage of low-income level households. This explains the finding that many shoppers are weekly remunerated, make frequent shopping trips to the mall (at least once a week), but spend a relatively small amount during each visit. Marketers can make the most of this situation by having special promotions and price deals targeting the mid-month shopper during the normally slack period of the month.

\section{Month-end shopper definition 3}

Month-end shopper: from the 26th of the month until the second day of the successive month and/or the last Friday of the month.

In the case of month-end shopper definition 3, the respondent variables differ significantly in only two instances (see Table 4) - the reason for shopping (lifestyle variable) and the average amount spend (user behaviour variable).

The average amount spend by shoppers during a shopping trip and the reason for shopping are the only variables on which month-end and mid-month shoppers differ significantly throughout, even at the $99 \%(=0.01)$ and $95 \%$ confidence levels $(=0.05)$ respectively, for all three shopper definitions. This serves as further confirmation of the theory that shoppers who have a low frequency of visits to a mall, usually embark on a single big monthly shopping expedition when groceries and other household goods are bought. Midmonth shoppers embark more regularly on smaller shopping expeditions. This has important applications for the retailoriented mass media and shopping mall tenants alike.

It is evident that statistically significant differences in varying degrees exist between the demographic, lifestyle, and user behaviour characteristics of the month-end and the midmonth shopper visiting the shopping mall. The resulting sample bias when shopping mall-intercept surveys are conducted on the busy three days at month-end, as is common practice among most research houses, is consequently caused by a relatively high degree of selection error, as was illustrated.

\section{Summary and conclusions}

In this article, a time-based systematic sampling method for use in shopping mall-intercept surveys was developed. Essentially, it involves measuring shopper traffic counts for all points of access/egress by time segments and selecting timelocation clusters with probabilities proportionate to size. Systematic sampling is then applied within the selected clusters.

This article also addressed the gap in research literature on the reduction of selection error in the use of the shopping mall-intercept interviewing technique.

The results presented in this article leave little doubt that haphazard sampling procedures in shopping mall-intercept surveys can detrimentally affect shopper profiles, trade area maps, market potential and penetration measurement, to mention but a few aspects. This can have serious consequences for marketing practitioners.

The issues of time-based versus traditional month-end sampling and length-biasedness showed significant effects. It was proved that great care has to be taken when sampling in a shopping mall as the demographic and lifestyle profiles of the month-end shopper differ, significantly, from that of the midmonth shopper based on three different definitions thereof. The longer the sampling period, the closer the profile of the mid-month shopper moves to that of the month-end shopper.

Sudman (1980: 427) suggested 'ideal' sampling procedures for human populations in mall surveys that included controls for location and time. These were heavily criticized by other resedrchers to the extreme of stating that most of his recommendations were 'unrealistic' (Gates \& Solomon, 1982: 46) and 'raise the cost of a shopper survey dramatically' (Blair, 1983: 106). The authors of this article disagree with the latter statement as their solution to time-biasedness, which also

Table 4 Month-end shopper: definition 3

\begin{tabular}{lcccc}
\hline Respondent characteristic & $\begin{array}{c}\text { Mid-month } \\
\mathrm{n}=216\end{array}$ & $\begin{array}{c}\text { Month-end } \\
\mathrm{n}=132\end{array}$ & $\begin{array}{c}\mathrm{Z}_{\text {- }} \\
\text { value }\end{array}$ & $\begin{array}{c}\text { t-Statistic } \\
\text { probability }\end{array}$ \\
\hline Residential area & 0.585 & 0.587 & -0.0303 & 0.3988 \\
Average amount spend & 0.699 & 0.455 & 4.5208 & $0.0000^{* *}$ \\
Method of payment & 0.855 & 0.888 & -0.8811 & 0.2709 \\
Remuneration method & 0.701 & 0.740 & -0.7827 & 0.2943 \\
Income of household & 0.574 & 0.473 & 1.8331 & 0.0748 \\
Occupation & 0.167 & 0.167 & 0.0000 & 0.3989 \\
Marital status & 0.505 & 0.545 & -0.7247 & 0.3079 \\
Number of children & 0.736 & 0.667 & 1.3762 & 0.1539 \\
Home language & 0.685 & 0.727 & -0.8303 & 0.2827 \\
Age & 0.556 & 0.644 & -1.6192 & 0.1074 \\
Gender & 0.764 & 0.720 & 0.9165 & 0.2613 \\
Ethnic group & 0.806 & 0.813 & -0.1611 & 0.3939 \\
Reason for shopping & 0.074 & 0.154 & -2.3687 & $0.0241^{*}$ \\
Shopping frequency & 0.412 & 0.379 & 0.6099 & 0.3312 \\
\hline * Significant at 95\% confidence level & & & \\
** Significant at 99\% confidence level & & & & \\
\hline
\end{tabular}


incorporates a sample clustering approach, increases total survey costs by only about $15 \%$.

\section{Managerial implications and recommendations}

Marketing practitioners need information about their markets, customers, products, and competitors in order to make the correct decisions to survive in the competitive world of today. Peace of mind with regard to the reliability and validity of marketing research information is therefore vitally important to them

Not only is the cost of obtaining marketing research information relatively high, but the negative impact that incorrect information could have on company profits is far greater.

The shopping mall-intercept survey is a very popular method used by research agencies to gather information of almost all kinds. Because mall-intercepts are vulnerable to various types of sampling bias, in particular selection bias, greater care has to be exercised when designing a sampling plan for a shopping mall. The different shopper profiles during the different times of the month could provide the marketing researcher, or even the shopping mall manager, for that matter, with the 'wrong' target market mix. In the words of Prinsloo:

'If you know your customer you can identify your trade area. If you know your trade area you can identify your customer' (1992: 26).

Marketing practitioners should insist that research agencies must inform them if research data is to be collected in a shopping mall. Furthermore, they should insist that the agency uses a sampling plan in mall-intercept surveys which reduces selection error in that it employs a methodology which is designed to reduce this error. Two basic requirements in this regard is that (a) the data collection period covers a full calendar month; and (b) a time-based systematic sampling technique be used.

Further research is definitely required to establish whether the demographic, lifestyle and user behaviour characteristics of shoppers also differ at other shopping malls located in other geographical areas during other times of the year.

Shopping mall-intercept surveys are a valuable tool for retail merchants, but some of their value could be lost by sampling practices currently being used by research houses. Timebased intercept sampling, as described in this article, is a definite improvement on these practices and well within current knowledge.

\section{Note}

1. Using the following formula:

$$
Z_{t}=\frac{\left(p i_{1}-p i_{2}\right)}{\left(S p i_{1}-p i_{2}\right)}
$$

where $\left(\mathrm{Spi}_{1}-\mathrm{pi}_{2}\right)$ equals:

$$
\sqrt{ }\left[\mathrm{P}^{*}(1-\mathrm{P} *)\right] \cdot\left[\frac{1}{n_{1}}+\frac{1}{n_{2}}\right]
$$

and

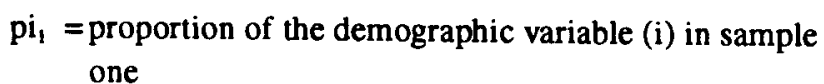

$\mathrm{pi}_{2}=$ proportion of the demographic variable (i) in sample two $\mathrm{n}_{1}=$ size in sample one

$\mathrm{n}_{2}=$ size in sample two.

\section{References}

Aaker, D.A. \& Day G.S. 1990. Marketing research. New York, NY: John Wiley \& Sons, Inc., fourth edition.

Alreck, P.L. \& Settle, R.B. 1985. The survey research handbook. Homewood, IL: Richard D. Irwin, Inc.

Assael, H. 1995. Consumer behavior and marketing action. Cincinnati, $\mathrm{OH}$ : South Western College Publishing, fifth edition.

Blair, E. 1983) 'Sampling issues in trade area maps drawn from shopper surveys', Journal of Marketing, 47: 98-106.

Boyd, H.W., Westfall, R. \& Stasch, S.F. 1985. Marketing research: text and cases. Homewood, IL: Richard D. Irwin Inc., sixth edition.

Bush, A.J. \& Hair, J.F. 1985. 'An assessment of mall intercept as a data collection method', Journal of Marketing Research, 22(2): 158-167.

Bush, A.J. \& Parasuraman, A. 1985. 'Mall intercept versus telephone interviewing environment', Journal of Advertising Re. search, 25(2): 36-43.

Churchill, G.A. 1992. Basic marketing research. Orlando, FL: The Dryden Press, second edition.

Demby, E.H. 1990. 'ESOMAR urges changes in reporting demographics Issues Worldwide Report', Marketing News, January 8 : 24-25.

Dillon, W.R., Madden, T.J. \& Firtle, N.H. 1993. Essentials of marketing research. Homewood, IL: Richard D. Irwin, Inc., first edition.

Dillon, W.R., Madden, T.J. \& Firtle, N.H. 1990. Marketing research in a marketing environment. Homewood, IL: Richard D. Irwin, Inc., second edition.

Dupont, T.D. 1987. 'Do frequent mall shoppers distort mall-intercept survey results?', Journal of Advertising Research, 27(4): 46-52.

Fowler, F.J. 1993. Survey research methods. Newbury Park, CA: SAGE Publications, Inc., second edition.

Gates, R. \& Solomon, P.J. 1982. 'Research using the mall intercept: state of the art', Journal of Advertising Research, 22(4): 43-49.

Hawkins, D.I. \& Tull, D.S. 1994. Essentials of marketing research. New York, NY: MacMillan Publishing Company, second edition.

Market Facts, Inc. 1987. Practices, trends and expectations for the market research industry 1987. Chicago, IL: Survey Report.

Murry, J.P. Jr., Lastovicka, J.L. \& Bhalla, G. 1989. 'Demographic and lifestyle selection error in mall-intercept data', Journal of Advertising Research, 29(1): 46-52.

Nakanishi, M. 1978. 'Frequency biases in shopper surveys'. In Proceedings of the American Marketing Association Educators' Conference. Chicago, IL: 67-70.

Nowell, C. \& Stanley, L.R. 1991. 'Length-biased sampling in mall intercept surveys', Journal of Marketing Research, 28: 475-479.

Prinsloo, D. 1992. 'Getting answers to questions', Shopping Centre Profile, February, 20-26.

Reid, P.M. 1989. 'Purists may disagree, but almost all types of surveys can be conducted in malls', Marketing News, 18: January 6.

Schiffman, L.G. \& Kanuk, L.L. 1994. Consumer behavior. Englewood Cliffs, NJ: Prentice-Hall International, Inc., fifth edition.

Solomon, M.R. 1996. Consumer behavior: buying, having, and being. Needham Heights, MA: Allyn and Bacon Publishing, third edition.

Sudman, S. 1980. 'Improving the quality of shopping center sampling', Journal of Marketing Research, 17: 423-431.

Tull, D.S. \& Hawkins Del I. 1990. Marketing research: measurement and method. New York, NY: MacMillan Publishing Company, fifth edition.

Zikmund, W.G. 1994. Business research methods. Orlando, FL: The Dryden Press, fourth edition. 